[ documento ]

\title{
O mestre de Apipucos e o turista aprendiz
}

Gilda de Mello e Souza

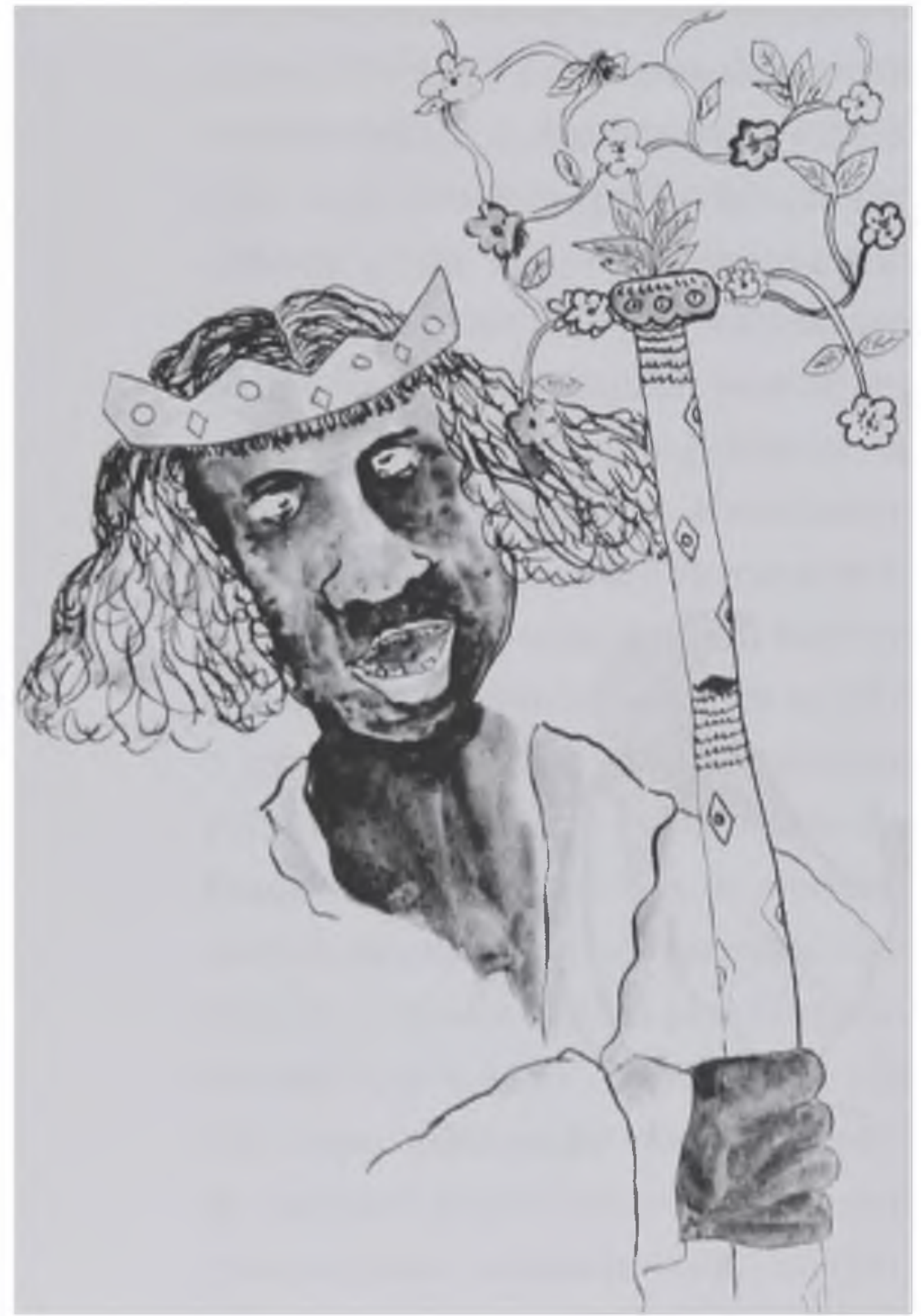




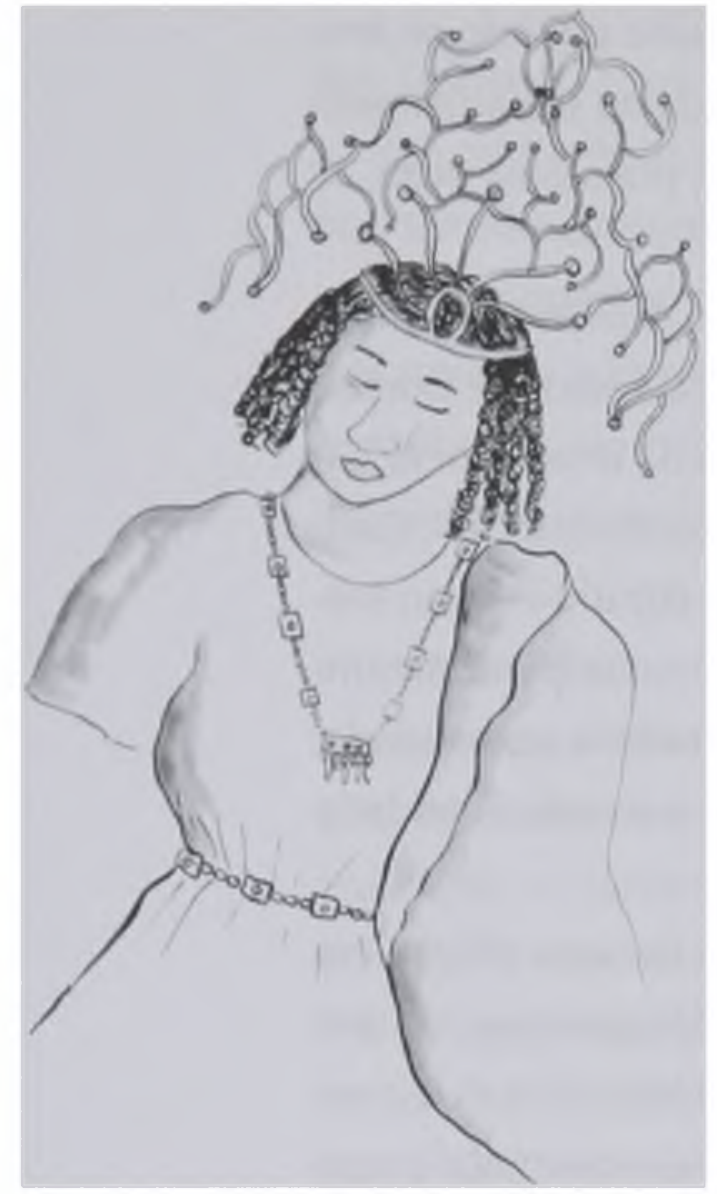

Resumo A autora estabelece um confronto entre os modos de interpretação do Brasil a partir das posiçōes de Mário de Andrade, em Macunaíma e O turista aprendiz, e de Gilberto Freyre em Casa-grande e senzala. Apesar das distinções interpretativas dos autores, o texto nos mostra que as obras se articulam em torno da análise de antagonismos da nossa formação cultural, vistos ora como vício ora como resistência.

Abstract This article faces two Brazil's interpretation ways, according to Mário de Andrade, in Macunaíma and $O$ turista aprendiz (The apprentice tourist), and, on the other hand, Gilberto Freyre, in Casa-grande e senzala. Despite the interpretative differences between these writers, the essay demonstrates that the three works are established on na analysis of the antagonisms since the Brazil's cultural formation, which are showed sometimes as a vice, sometimes as a resistance.

Palavras-chave formação cultural • interpretaçāo do Brasil Keywords cultural formation - Brazil's interpretation 
Folheando recentemente uma coletânea de documentos sobre o modernismo brasileiro, deparei com dois artigos sobre Cícero Dias: um de Gilberto Freyre, outro de Mário de Andrade.' Achei curioso que os escritos mais ou menos contemporâneos, saudando as primeiras exposições do jovem pintor pernambucano no Rio de Janeiro e em São Paulo, no decênio de 1920, apresentassem concordância acentuada de pontos de vista. Sobretudo quando se leva em conta a espécie de oposição entre a Semana de Arte Moderna e o Movimento Regionalista do Nordeste, de que Mário e Gilberto foram, por assim dizer, os "chefes-de-fila"

E no entanto ali estavam, um ao lado do outro, os dois irmãos inimigos, exaltando em Cícero Dias as mesmas características: "a acuidade exacerbada da sensibilidade" "o desprezo pelos raciocínios fáceis da inteligência" "a atração pelos antagonismos" a "riqueza às vezes mórbida dos contrastes" Exaltando, enfim, a capacidade de representar pelo lápis e pela cor um mundo feérico e talvez mais real que o verdadeiro - "um outro mundo" - como diziam ambos, onde os valores principais eram, segundo Mário de Andrade, a sexualidade, o sarcasmo, o misticismo; onde "o sexo irrompia desigual e místico" na bela expressão de Gilberto Freyre.

Este acordo tranqüilo, que o confronto dos textos deixava aflorar, era inesperado, mas significava que, independente das discordâncias que sempre afastaram um do outro, existia entre os dois uma zona de trégua. Era como se, voltando as costas ao pensamento racional, aderissem espontaneamente a uma forma concreta de conhecimento, que, "a meio caminho do imaginário popular e do surrealismo" parecia mais adequada para captar o mundo fluido e fugidio da infância. Era o mundo patriarcal do nordeste brasileiro, feito de fragmentos desemparelhados da memória, enumerações exaustivas, confrontos insólitos, que Gilberto sabia com tanto encanto transportar para o universo da palavra:

Os corredores malassombrados de Jundiá, o quarto em que dona Chiquinha amanheceu morta enforcada nos cordões de S. Francisco, o quarto dos padres, o quarto dos santos, a cadeira de balanço que de noite se balança sozinha sobre um tijolo solto que de manhã ninguém descobre (talvez dinheiro enterrado do tempo dos Flamengos), os retratos de parentes em grandes molduras douradas, pastoris, sãojões, santoantonios, sãopedros, (com vivas ao coronel Pedrinho de Batateiras e a Pedro FiIho também), os Milhões de Arlequim tocados no piano pela mãe de Cícero, agora mor-

1 Brasil: $1^{0}$ tempo modernista - (1917-1929) Documentação. Pesquisa, seleção e planejamento de Marta Rossetti Batista. Telê Porto Ancona Lopez e Yone Soares de Lima. São Paulo: IEB-USP, 1972. 
ta, botadas, batisados, casamentos, enterros, carros de boi, cabriolés rodando pela areia frouxa, deslizando pelo barro mole, afundando gostosos em grandes e macias poças de lama, saltando pelo empedrado das ruas, Lord Carnavon - o de Tutankhamon - visitando o major, acompanhado pelo padre inglês vestido de preto (..... ${ }^{2}$

Em resumo: as diferenças notórias que, no decorrer dos anos, afastam Gilberto Freyre de Mário de Andrade não impediam a espécie de cruzamento que no decênio de 1920 os aproxima, quando o primeiro, depois da estadia nos Estados Unidos, volta para o Brasil e o segundo encerra com Macunaíma a etapa nacionalista que havia construído no gabinete. É o momento em que ambos pensam o Brasil moderno sem perder o contacto com a cultura popular e a contribuição do passado, embora cada um realize essa tarefa, como iremos ver, segundo seu temperamento e anseio cultural.

Gilberto, preso à sociedade açucareira do Nordeste, prefere defender a tradição, afirmando que o caminho da modernidade está na sabedoria portuguesa de equilibrar os antagonismos e conservar os elementos e as transformações "que atuaram de modo criador no desenvolvimento nacional" Interpreta a realidade social como "participante íntimo e ativo dos valores do grupo" - mas acrescenta com cautela - "criticamente e também com simpatia humana" Constrói a imagem do Brasil através da vivência regional e aceita, de bom grado, que o classifiquem como um "realista romântico" 3 Mário, ao contrário, procura evocar ou reviver o passado sem o transformar numa visão saudosista; sabe o quanto ele pesa em nossos gestos, mas prefere tradicioná-lo em valor atuante e referido ao presente. Não é um aristocrata, mas um homem comum, urbano, pragmáti$\mathrm{co}$, que insiste em se confessar sem memória - pessoal ou de grupo - para dissolver melhor as particularidades locais numa concepção ampla de nacionalismo.

No entanto, se é possível aproximar dois intelectuais diversos como Mário e Gilberto, não será descabido - como desejo fazer agora - cotejar a narrativa mágica, mítica do primeiro, com o grande ensaio sobre a formação da sociedade brasileira do segundo? Macunaíma é sem dúvida, um livro precursor, mas como o próprio autor declara num dos prefácios inéditos que escreveu, "é uma invenção sem compromisso, característica das épocas de transição" Não pretende ser uma análise da realidade. Não obstante, exprime a seu modo uma opinião sobre o Brasil e descreve, através do personagem central, um tipo ve-

2 lbidem, p. 167.

3 FREYRE, Gillberto. Região e tradição. Rio de laneiro: José Olympio, 1941, p. 22-42 
rossímil de brasileiro, um homem fisicamente indeterminado, psicologicamente contraditório, disputado por tendências conflitantes que não consegue harmonizar: a indolência da selva, de onde provém, e a atração do mundo ordenado da cidade, para onde se dirige. Um dos achados da narrativa foi conceber este herói negativo - sem caráter, sem identidade, sem projeto - sempre correndo, sempre atarefado como um homem de ação. E se está sempre a caminho, não é porque ande em busca do destino, mas porque a estrada é o lugar do homem sem rumo, do deserdado. Por muito tempo este traço ambíguo e perturbador foi obscurecido pela feição mais aparente do livro, a força da sátira e a exploração intencionalmente grosseira da obscenidade. Mas com o passar dos anos, quando foi possível cotejá-lo com o conjunto da obra de Mário de Andrade e a temática dominante do período, viu-se que Macunaíma não fôra uma explosão isolada, mas o primeiro tratamento sério de um dos temas do momento: a irresolução dramática do brasileiro em face do próprio destino. Mário de Andrade voltaria a ele, obsessivamente, no ensaio, na prosa, na poesia e, como veremos, num livro de viagem, O turista aprendiz ${ }^{4}$

Casa-grande e senzala5, publicado em 1933, cinco anos depois de Macunaíma, portanto, é muito diferente da narrativa mítica, fantástica de Mário. É um ensaio de "sociologia genética e histórica social" como o próprio autor declara, e se apoia em bibliografia rigorosa e atualizada para a época. Apesar disso os dois livros podem ser tomados como obras complementares, na medida em que se articulam em torno do mesmo suporte, que é a análise da preguiça e dos antagonismos que regem a nossa formação cultural.

De certo modo o grande livro de Gilberto Freyre se reduz a uma exposição exaustiva e brilhante de como construímos a nossa cultura, partindo do equilíbrio instável dos antagonismos herdados de Portugal. Isto é, herdamos da metrópole o confronto cultural permanente que já caracteriza a Colônia, a espécie de bicontinentalidade, "que em população vaga e incerta como a portuguesa e brasileira, corresponde ao que é a bissexualidade para o indivíduo" Este traço dominante se reflete em todos os setores de nossa existência: na indecisão étnica, no regime alimentar, na concepção de vestimenta, de moradia, nas manifestações de prestígio, e assim por diante. Somos indeterminados em todos os sentidos, desde o tipo físico, em que o correr dos anos transforma o

4 ANDRADE, Mário de. O turista aprendiz. Estabelecimento de texto, introdução e notas de Telê Porto Ancona Lopez. 2a ed. São Paulo: Duas Cidades, 1983

5 FREYRE, Gilberto. Casa-grande e senzala - formação da familia brasileira sob o regime de economia pa-

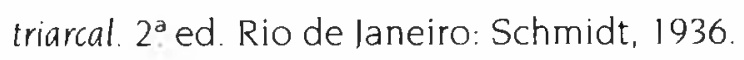


louro luminoso da criança no louro mortiço do adulto, ou na estranha invenção dos "mestiços com duas cores de pêlo"6 Na vestimenta e na habitação, que conservam o velho hábito português de opor o desleixo da roupa caseira e a dieta frugal do dia-a-dia à ostentação da toilette de domingo e à comezaina das grandes festas. "Às vezes guenzos de fome - comenta Gilberto Freyre - mas sempre de roupa de seda ou veludo, dois, três, oito escravos atrás, carregando-lhes escova, chapéu de sol e pente. No contraste freqüente entre a moradia inóspita e a exibição pública de luxo e riqueza, que ele resume numa fórmula impiedosa: "Palanquins forrados de seda, mas telha-vã nas casas-grandes e bicho caindo na cama dos moradores."7 Ou nas duas maneiras de falar - "uma de luxo, oficial, outra popular, para o gasto" - que aparecem, por exemplo, na colocação de pronomes e cuja análise admirável merece ser transcrita por inteiro

Um exemplo e dos mais expressivos que nos ocorre é o caso dos pronomes. Temos no Brasil dois modos de colocar pronomes, enquanto o português só admite um - o "modo duro e imperativo" (loão Ribeiro): diga-me, faça-me, espere-me. Sem desprezarmos o modo português, criamos um novo, inteiramente nosso, caracteristicamente brasileiro: me diga, me faça, me espere. Modo bom, doce, de pedido. E servimo-nos dos dois. Ora, esses dois modos antagônicos de expressão, conforme necessidade de mando ou cerimônia, por um lado, e de intimidade ou de súplica, por outro, parecem-nos bem típicos de relações psicológicas que se desenvolveram através da nossa formação patriarcal entre os senhores e os escravos; entre as sinhás-moças e as mucamas; entre os brancos e os pretos. "Faça-me" é o senhor falando, o pai, o patriarca; "me-dê" é o escravo, a mulher, o filho, a mucama. Parece-nos justo atribuir em grande parte aos escravos, aliados aos meninos das casas-grandes, o modo brasileiro de colocar pronomes. Foi a maneira filial e mais dengosa que eles acharam de se dirigir ao pater familias. ${ }^{8}$

Como se vê, tudo à nossa volta revela, para Gilberto, aquele antagonismo que ele já divisara em Cícero Dias - um Brasil que não é

de um lado nem de outro mas dos dois - com esse sentido lírico bissexual. essa compreensão de branco e preto, de senhor e escravo, de pessoa e animal, de homem e cousa, de macho e fêmea, de santo e fetiche, de azul e encarnado, a que o poe-

6 Idem. Ver todo o capítulo 3, sobretudo p 142-3.

7 Idem, p 39

8 Idem, p. 246.

77 Gilda de Mello e Souza 
ta (...) tem de atingir antes de poder interpretar a vida brasileira no seu conjunto, na sua profundidade, no seu todo ${ }^{9}$

Pela originalidade dos pontos de vista, pela maneira inovadora de interpretar o país através dos pequenos indícios, Gilberto Freyre logo se impôs à minha geração. Sobretudo pela determinação com que valorizou o negro em relação ao aborígene. Inventado pelo romantismo, o álibi do indianismo havia resistido com galhardia até a Semana de 22, no início desse século, permanecendo vivo mesmo em obras revolucionárias como Macunaíma, a Antropofagia e formulações abastardadas como o movimento da Anta. Gilberto deu um golpe de graça nessa sobrevivência despistadora, demonstrando a importância muito maior da cultura africana. E embora não seja possível desmistificar do dia para a noite um preconceito arraigado, pode-se afirmar, sem exagero, que a partir dele a discussão sobre a mestiçagem brasileira não foi mais a mesma.

Gilberto nos fascinou ainda pelo estilo literário admirável, o senso de composição, a relação extraordinária que mantinha com as palavras - "com as palavras entre si e até as vírgulas e os pontos" - como fazia questão de precisar; pela sensualidade verbal, capaz de harmonizar longos trechos de prosa prousteana com processos enumerativos, colhidos no povo ou nas experiências sofisticadas das vanguardas. Que outro sociólogo ou historiador teria a ousadia de elaborar as sínteses luminosas que ele inventava para definir a colonização portuguesa?

Colônia fundada quase sem vontade, com um sobejo apenas de homens (...) o Brasil foi por algum tempo a Nazareth das colônias portuguesas. Sem ouro nem prata. Somente pau-de-tinta e almas para Jesus Cristo.

Ou as fórmulas lapidares a que sabia reduzir a decepção da descoberta: O Brasil foi como uma carta de paus puxada num jogo de trunfos em ouros. 10 Mário de Andrade levou algum tempo para ordenar as idéias sobre o Brasil. A correspondência com o grande amigo Manuel Bandeira é um testemunho excelente desse período de perplexidade e reavaliações que vai de 1925 a 1927. quando está empenhado em combater a Europa, esquecer Portugal e, em seguida, encerrar a fase que apelidara com ironia de "nacionalismo de estandarte" Está desgostoso com a acolhida fria, quase indiferente feita a seu ro-

9 Brasil: 1 tempo modernista - (1917-1929) Documentação, op. cit., p. 168.

10 FREYRE, Gilberto. Casa-grande e senzala, p. 138 
mance mais psicológico e cosmopolita Amar verbo intransitivo - que ele considera, no entanto, uma realização importante - e aguarda o aparecimento de Macunaíma e Clã do jaboti, ambos no prelo, para se dedicar a trabalhos que deseja recatados e esteticamente independentes.

É neste momento de transição que devemos situar um episódio decisivo em sua biografia intelectual: as duas viagens que realiza ao Norte e Nordeste do Brasil, em 1927 e 1929, cujos relatos, reunidos em O turista aprendiz, só virão a público em 1976, trinta e um anos depois de sua morte. São as duas únicas travessias longas que faz em toda a vida e ele as realiza aos trinta e quatro anos, quando é um escritor conhecido e já traçou as coordenadas do destino. Há um detalhe importante que deve ser ressaltado. Enquanto as viagens de recreio da burguesia seguiam, invariavelmente, a rota Brasil-Europa, esta viagem invertia o itinerário internacional. Ao se dirigir do sul europeizado para o Nordeste e a região amazônica, Mário de Andrade não visava apenas identificar-se com a diferença brasileira, mas confrontar duas imagens diversas do Brasil: a que ele forjara no gabinete através de uma infinidade de leituras - e de certo modo fixara em Macunaíma - e a que pretendia elaborar agora, a partir do contacto direto com a realidade. Se para esclarecer o que desejo afirmar me permitem uma analogia com a pintura, eu diria que, naquele momento, Mário de Andrade era protagonista de uma experiência, semelhante à dos pintores impressionistas, que na segunda metade do século xIx, na França, desgostosos com a estética imposta nas escolas de belas-artes, abandonam o ateliê e saem para a natureza e a execução junto ao motivo. É um Brasil visto pela primeira vez ao ar-livre que Mário de Andrade pretende enfrentar, quando em 1927 toma no sul o Pedro 1, contorna o litoral até o extremo norte e, já numa embarcação fluvial, sobe "pelo Amazonas até o Peru, pelo Madeira até a Bolívia, por Marajó até dizer chega" 11 O turista aprendiz é o registro dessa aventura extraordinária.

Pelas anotações de viagem, registradas desde o bota-fora da Estação da Luz, em São Paulo, sabemos que Mário partiu tenso e agoniado, como quem se encontra no limiar de uma experiência decisiva. "Estou sorrindo, mas dentro de mim vai um arrependimento assombrado, cor de incesto" confessa numa frase reveladora. Todo o início da travessia marítima é dominado por um sentimento curioso de insegurança, como se estivesse sendo disputado por duas personalidades em conflito. "Faz uns seis dias que vivo em dois homens" registra no caderninho de notas que traz sempre à mão. À medida que o navio avan-

11 Subtítulo humorístico que o autor acrescentou ao título do livro. 
ça, rumo a um país desconhecido, ele se esforça para recobrar o equilíbrio e se reunificar. Ou antes, "perder o caráter de uma vez" "dissolver" a personalidade originária para poder ingressar em outra realidade, sugerida pelas "delícias refinadas da tonteira" pelo "som de chuva das ondas" Lentamente vai acrescentando à embriaguez espontânea, provocada pelo balanço do mar, o artifício eficaz do álcool e do sedol. Sente, aos poucos, que "se desumaniza". principalmente "se desoperariza" "Perco esta parte de operário que tem em mim, tão vasta e muito nobre - a melhor parte de mim" comenta. Finalmente anota, com extraordinária lucidez: "Perco o sul de minha personalidade" 12

Quando chega a Salvador verifica que a "memória literalista da inteligência" já o abandonou. E é reduzido à "memória do corpo" a uma percepção nova, cuja "simultaneidade é feroz" lembra o "cinema alemão". que avista a cidade:

Parece incrível que se tivesse construído uma cidade assim... Ruas que tombam, que trepam, casas apinhadas e com tanto enfeite que parecem estar cheias de gente nas janelas, o barulho nem é tamanho assim porém dá impressão de enorme, um enorme grito. 13

Ao deixar a embarcação marítima e penetrar no continente pelo rio Amazonas, registra que já não tem mais controle sobre si mesmo e está se deixando abater pelo "êxtase" e pela "volúpia". A caminho de Manaus escreve a Manuel Bandeira uma longa carta, comentando detalhadamente a "vida de pura sensibilidade" a que se entregou:

O êxtase vai me abatendo cada vez mais. Me entreguei com uma volúpia que nunca possuí à contemplação destas coisas, e não tenho por isso o mínimo controle sobre mim mesmo. A inteligência não há meios de reagir nem aquele poucadinho necessário pra realizar em dados ou em bases de consciência o que os sentidos vão recebendo. Estou completamente animalizado. 14

Como se vê, ele está consciente de que a primeira parte da viagem se caracterizou, sobretudo, pela renúncia à razão; pelo esquecimento gradativo de tudo o que, até aquele momento, Ihe havia norteado a vida - a saber, os conceitos abstratos, as normas de conduta, as decisões dos projetos. O contato com a realidade inesperada de seu país, como que restaurou nele um estado de inocência, de disponibilidade perceptiva, e é nesse enquadramento novo e despo-

12 ANDRADE, Mário de O turista aprendiz, op. cit., p. 210.

13 Idem, p. 213.

14 Idem, Cartas a Manuel Bandeira. Rio de Janeiro: Simões, 1958, p. 166. 


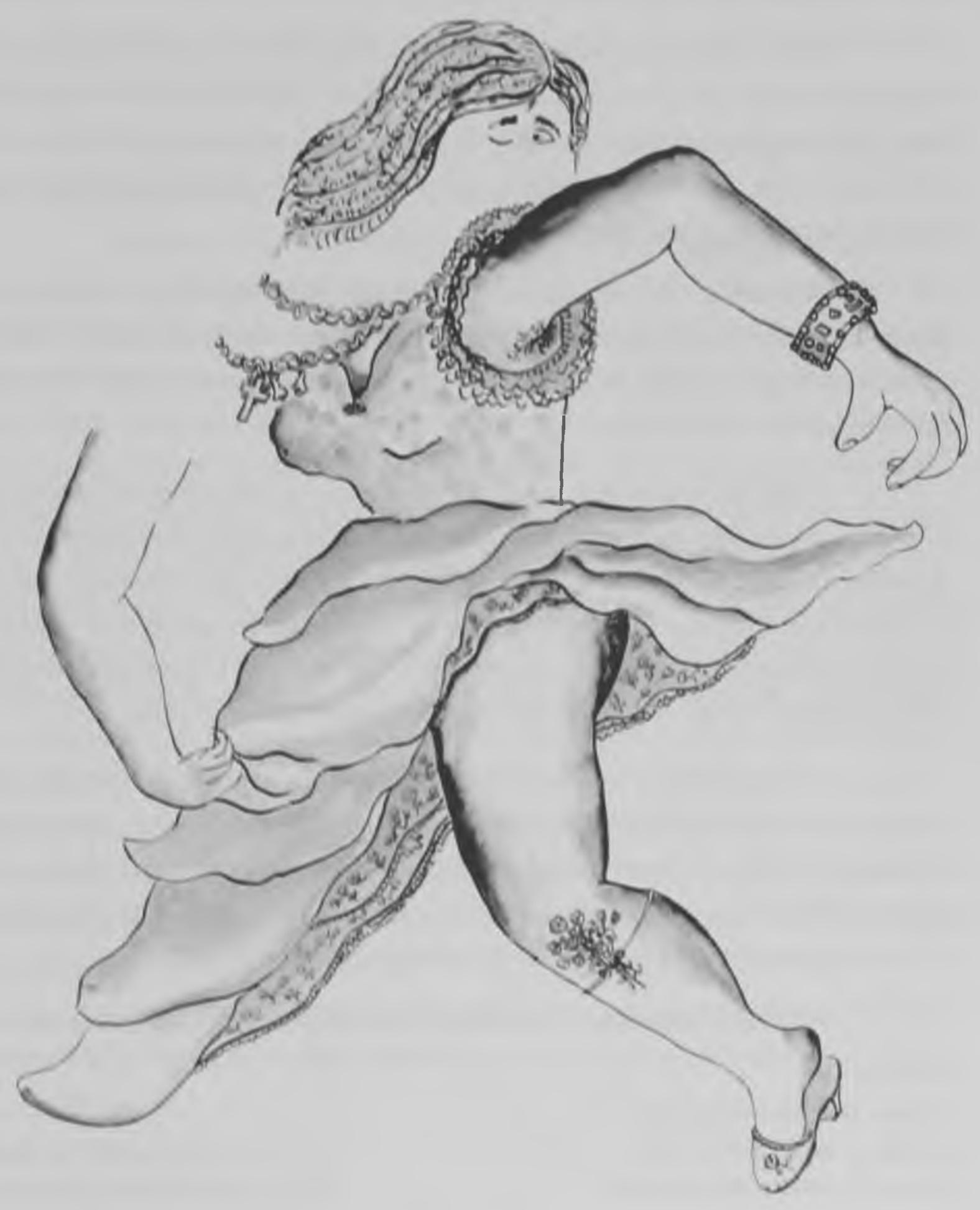


jado que, de agora em diante, tem de ir organizando, lentamente, as impressões. Por isso registra tudo com o rigor metódico de quem está refazendo o saber: o gosto das frutas, a variedade dos cheiros, a sutil variação térmica da atmosfera:

Esta variedade infinita de calores amazônicos. Batia um calor fresquinho no furo. Ontem, depois da chuva, bateu um calor tão frio que as mulheres daqui se cobriram. E dizem que lá dentro, quando estivermos de fato no coração do imenso rio, tem madrugadas tão úmidas que a gente chega a tiritar de calor. ${ }^{15}$

Indaga do paladar das frutas, tentando definir, indeciso, o gosto insólito, inconfundível, de cada uma delas:

Nesta noite provei sorvete de graviola. Esquisito (...) a graviola tem gosto de graviola mesmo, isso é incontestável, mas não é um sabor perfeitamente independente. É antes uma imagem, uma metáfora, uma síntese apressada. É a imagem de todas essas ervas, frutas condimentares, que, insistindo são profundamente enjoativas. Não chega a ser ruim, mas irrita. ${ }^{16}$

Se esforça, com simpatia, para aceitar o "ruim esquisito" o sabor selvagem, tão diferente do gosto familiar, doméstico, das frutas européias. Quando prova o açaí, se detém indeciso, confuso como um jovem polido tendo de opinar sobre uma moça feia:

O açaí não chega a ser ruim (...) Pousa macio na boca da gente, é um gosto de mato pisado, não gosto de fruta, de folha. E logo vira moleza, quentinha na boca, levemente saudoso, um amarguinho longínquo que não chega a ser amargo e agrada. Bebida encorpada que, por mais gelo que se ponha, é de um quentezinho amável, humilde, prestimoso. É um encanto bem curioso o do açaí! (...) A gente principia gostando por amabilidade e depois continua gostando porque tem dó dele. ${ }^{17}$

E como descrever - ele tão sensível ao aspecto visual da natureza - o colorido do mundo equatorial, inundado de luz? Existirão matizes, gradações, capazes de resistir ao "branco feroz, desesperante, luminosíssimo, absurdo, que penetra pelos olhos, pelas narinas, poros" como o que o surpreende em Mara¡ó? Como apreender as cores na rapidez vertiginosa do crepúsculo?

Fez crepúsculo em toda a abóbada celeste, norte, sul, leste, oeste. Não se

15 Idem, O turista aprendiz, p. 64.

16 Idem, O turista aprendiz, p. 84.

17 Idem, O turista aprendiz, p. 183 
sabia pra que lado o sol deitava, um céu todinho em rosa e ouro, depois lilás e azul, depois negro e encarnado se definido com furor. Manaus a estibordo. As águas negras por baixo. 18

E a súbita revoada dos pássaros na boca do lago Arari?

Garças, garças, garças, uma colhereira dum rosa vivo no ar! E enfim passamos num primeiro pouso de pássaros que me destrói de comoção. Não se descreve, não se pode imaginar. São milhares de guarás encarnados, de colhereiras cor-derosa, de garças brancas, de tuiuiús, de mauaris, branco, negro, cinza, nas árvores altas, no chão de relva verde claro. E quando a gente faz um barulho de propósito, um tiro no ar, tudo voa em revoadas doidas, sem fuga, voa, baila no ar, vermelhos, rosas, brancos mesclados, batidos de sol nítido. ${ }^{19}$

Tudo lhe parece tão novo e diverso, que ele às vezes pára, "hesitando em contar certas coisas, com medo que não acreditem"

Desde as dunas do Nordeste ele vem cedendo à presença impositiva do mundo exterior, vem cedendo à vida equatorial, tão mais objetiva que a vida do Sul. Tem a impressão que no Norte a parte resguardada das coisas e das pessoas desapareceu, e tudo surge como que "revestido de uma epiderme violenta, perfeitamente delimitada, sem mistérios" Talvez por isso, por causa dessa "franqueza" dessa "sensualidade contagiante de contacto" que envolve tudo e ele procura preservar, quando depara, na beira do Jutaí, com as índias aculturadas que se aproximam do navio em suas embarcações, pode senti-las em perfeita sintonia com a sua sensibilidade de ocidental. Isentas de qualquer avaliação de exotismo, lindas e femininas em seu "tipo asiático perfeito" em sua "fineza esplêndida de linhas" E é com naturalidade, quase com enlevo que lhes descreve a vestimenta, "a saia apertada na cintura nua, a espécie de blusa encarnada (...) que caía solta em pregas até o ventre (...) só tapando os seios" o babado que, cobrindo os ombros, deixava "o costadinho de fora" Como se descrevesse a roupa de uma amiga, nada que se assemelhasse à "preocupação impertinente com o sexo" que, em outros escritos, ele reprovou no olhar cúpido dos primeiros cronistas e viajantes.

À medida que tenta se identificar de corpo e alma com o país, surpreendendo-o à luz do ar livre, sente crescer a suspeita antiga de que a acomo-

18 Idem, O turista aprendiz, p. 133

19 Idem, O turista aprendiz, p. 176-7 
dação entre nós da cultura européia não foi uma solução feliz. O registro que faz, no caderninho de bolso, a 18 de maio, exprime bem esta perplexidade:

Por enquanto, o que mais me parece é que tanto a natureza como a vida destes lugares foram feitos muito às pressas, com excesso de castroalves. E esta prénoção invencível, mas invencível, de que o Brasil, em vez de se utilizar da África e da Índia que teve em si, desperdiçou-as, enfeitando com elas apenas a sua fisionomia, suas epidermes, sambas, maracatus, trajes, cores, vocabulários, quitutes (...) E deixou-se ficar, por dentro, justamente naquilo que, pelo clima, pela raça, alimentação, tudo, não poderá nunca ser, mas apenas macaquear, a Europa. Nos orgulhamos de ser o único grande (grande?) país civilizado tropical (...) Isso é o nosso defeito, a nossa impotência. Devíamos pensar, sentir como indianos, chins, gente de Benin, de lava (...) Talvez então pudéssemos criar cultura e civilização próprias. Pelo menos seríamos mais nós, tenho certeza. ${ }^{20}$

A idéia de que a transposição para os trópicos de um sistema de referências tipicamente ocidental não se harmonizava à realidade brasileira é expressa por Mário de Andrade em vários trechos das anotações. Não só de maneira explícita, como na passagem que acabei de citar, mas numa série de referências indiretas, alusões, parábolas, pequenas alegorias satíricas e mesmo episódios reais levemente dramatizados. Detenhamo-nos em duas destas exemplificações.

A primeira é a monografia humorística de suposta tribo indígena da Amazônia - os Do-Mi-Sol - cujos traços culturais se dispõem de modo simetricamente oposto aos nossos. ${ }^{21}$ Estes índios constituem uma espécie de matrecracia comunista, em que a distribuição coletiva das ocupações tem por base, curiosamente, a injustiça, para que nunca na tribo haja nas contendas razão plausível de queixas. Os Do-Mi-Sol possuem uma mitologia francamente demonológica e, como não conhecem o conceito do Bem, não cultuam nenhuma divindade boa. Além disso, embora possuam a fala, não se comunicam, como nós, através do som verbal das palavras. Isto é, fazem justamente o contrário, dando sentido intelectual aos sons musicais e valor meramente estético aos sons articulados e palavras. Possuem, por esta razão, um número muito maior de sons que os da nossa pobre escala cromática, sendo freqüente descobrirmos em seu discurso o quarto-de-som, não raro o quinto-de-som e, na prosa dos membros

20 ldem, p. 61

21 Idem. Os Do-Mi-Sol, inicialmente designados como os Pacáas novos, são descritos às p. 90-3. 127, 140-1, 158, 161-2 e 164 . 
mais eruditos da tribo, como por exemplo, os filósofos, palavras em que entram os sexto-de-som. A relação que os Do-Mi-Sol mantém com o pudor é em tudo oposta à que adotamos, pois fazem em público as necessidades e os demais atos que reputamos privados, mas em contrapartida fecham-se na mais absoluta intimidade, para realizar escondidos as refeições. Originariamente os DoMi-Sol descendem das preguiças. Ou melhor, da luta milenar entre guaribas e preguiças, em que os últimos foram vencedores.

Esta historieta, que procurei resumir, não desempenha n'O turista aprendiz um papel apenas ornamental. Sugerida pela experiência extraordinária da viagem, ela tem como objetivo nos alertar para a relatividade dos códigos. sempre abertos para leituras alternativas. À semelhança dos estratagemas óticos, postos em voga pela psicologia-da-forma - em que num desenho intrincado podemos ler, indiferentemente, a figura como fundo e o fundo como figura Mário nos força através deste exemplo a apreender um traço que supúnhamos natural, como aberrante, e uma aberração como um simples traço cultural. Assim, o mundo de cabeça-para-baixo que nos é descrito aqui antecipa e reforça, como veremos a seguir, o episódio do maleitoso, que irá encerrar a viagem e a longa meditação sobre o Brasil.

Neste segundo episódio ${ }^{22}$, quase um apólogo, Mário de Andrade relembra com minúcia, a impressão profunda causada nele e nas companheiras de viagem pelo moço comido de maleita que, em certo momento da travessia fluvial, sobe no vaticano para negociar com as autoridades da embarcação as peles de borracha de seu seringal. O Vitória descia o rio Madeira, já na volta a Belém, e havia parado na boca de um igarapé, numa dessas tardes "incomparáveis" do Norte, de "pasmaceira, de êxtase" - como ele as define - em que o ar se impregna de religiosidade. Eis que na curva do rio, saindo do silêncio e do mistério, surge da selva uma embarcação, avançando pesada na batida dos remos. É um casco com seis remeiros, que traz na proa o chefe da tripulação e, viajando em pé, no barco oscilante, demonstrando familiaridade com a água, um homem de seus trinta anos. A barba feita, o terno de linho branco muito limpo, a "sensação firme de decoro" que transmite, o "ar de soberbia" revelam que era dono ou filho de dono de seringal. A pele morena, muito pálida, traía a maleita.

O narrador descreve com respeito e admiração o comportamento do moço que, alheio à curiosidade que provoca, sobe a bordo para tratar dos recibos e faturas e, indiferente a tudo em redor, indiferente à beleza civilizada das

22 Idem, p. 159 
passageiras, passa sem olhar para ninguém. Apenas, por delicadeza natural, ao se aproximar das senhoras, tira o chapéu nativo de palha e vai-se como veio. Sem olhar. Tentando compreender o que presenciou Mário comenta:

Possivelmente se tratará de uma substituição de problemas, uma diluição de problemas dentro da indiferença. Ou dentro da paciência. Ou dentro da monotonia, que tem mais objetividade. São quase sete horas e nos comovemos na passagem diz-que difićlima de Marmelos. A imagem do moço me persegue. Ter uma maleita assim, que me deixasse indiferente. ${ }^{23}$

No conjunto de escolhas apaixonadas, que foi fazendo pela vida afora, o que significa esta declaração final, inesperada? O que significa esse desejo de maleita, que a partir da experiência amazônica se tornou uma obsessão em sua vida? A pergunta merece alguns esclarecimentos.

Inicialmente é preciso esclarecer que, para Mário de Andrade, a maleita não representa a moléstia endêmica, cruel e devastadora, que é preciso erradicar a qualquer custo. No sistema complexo de metáforas, equivalências, substituições que, elaborou à semelhança de um código, para pensar a realidade de seu país e a sua própria realidade interior - a maleita não está vinculada ao sofrimento. Aparece quase sempre reduzida à prostração que se segue às crises de febre e é aceita por ele como um estado de graça, uma etapa inicial de sabedoria. Mas deixemos que o próprio escritor nos esclareça a respeito:

Assim a obsessão da minha vida, não é o acesso de febre. Nem no acesso de febre se resume a filosofia da maleita, com perdão da palavra. Está claro que o meu desejo é mais elevado. Quero, desejo ardentemente é ser maleitoso não aqui, com trabalhos a fazer, com a última revista, o próximo jogo de futebol, o próximo livro a terminar. Desejo a doença com todo o seu ambiente e expressão, num igarapé do Madeira com seus jacarés, ou na praia de Tambaú com seus coqueiros, no silêncio, rodeado de deuses, de perguntas, de paciências. Com trabalhos episódicos e desdatados, ou duma vez sem trabalho nenhum. Quanto ao sofrimento dos acessos periódicos, não é isso que desejo, mas a prostração posterior, o aniquilamento assombrado, cheio de medos sem covardia, a indiferença, a semimorte igualitária [os grifos são meus|. ${ }^{24}$

Em resumo: na elaborada constelação de sinais em que Mário de Andrade projeta o seu imaginário, a maleita surge como o equivalente à paciência

23 Idem, p. 159

$24 \bigcirc$ trecho transcrito foi retirado da crônica do Diário Nacional, "Maleita I" (8.11.1931. p. 454) In: Mário de Andrade, Táxi e crônicas do Diário Nacional. Estabelecimento de texto, introdução e notas de Telê Porto Ancona Lopez. São Paulo: Duas Cidades, 1976. p. 454 
e à preguiça. Mas à preguiça organizada como ela vem descrita na alegoria dos índios Do-Mi-Sol, livre da conotação negativa que a linguagem comum lhe atribui. Agora os dois termos - maleita e preguiça - se perfilam intercambiáveis, exibindo o mesmo traço distintivo que os identifica: a indiferença. Ou melhor, o poder de resistir aos apelos do mundo.

Visto nesta perspectiva, o panteão privado de Mário de Andrade muda radicalmente, quando após a publicação de seu grande livro ele desloca o olhar que havia pousado em Macunaíma para fixá-lo no maleitoso. A escolha não era fortuita e resultara do confronto que fizera entre as duas civilizações: uma, voltada para o mundo exterior e dominada pelo ascetismo do trabalho; outra espiritual e mística, indiferente aos bens econômicos e absorvida no mundo interior. Esta última, semelhante às velhas civilizações que haviam florescido no Oriente e na África, talvez fosse capaz de aliviar a "imensa e sagrada dor dos irreconciliáveis" que habitava entre nós e - a seu ver - há tempos vinha alimentando, era impossível de ser realizada na prática, ele procura libertar-se dela dentro da arte. No "Rito do irmão pequeno"25 escrito poucos anos depois da viagem, ele transfere o paraíso sonhado para a poesia. Para o limbo ou nirvana de calmaria serena, pasmaceira, silêncio, em que na "sonolência dos enormes passados" ainda era possível

(...) entre palavras e deuses,

exercer a preguiça, com vagar.

Chegou o momento de retomar, à guisa de conclusão, o paralelismo com que iniciei esta longa análise. Vistos da perspectiva isenta da História, Gilberto Freyre e Mário de Andrade já não nos parecem solidários, como há tantos anos atrás. Gilberto Freyre, por direito ou por escolha, acabou fixando para a posteridade o perfil de aristocrata do Nordeste. Representa bem a ideologia da sociedade agrária da região, ao construir uma interpretação do Brasil muito briIhante mas conformista, e ao adotar, sem reserva, o esquema ocidental de referências, que privilegia o trabalho e interpreta a preguiça como vício. É compreensivo mas não é solidário. Dificilmente encontramos nele um sentimento de frustração diante da sociedade desarmônica que não deseja modificar, da mestiçagem que não diz respeito à sua linhagem e que ele analisa com a lucidez distanciada de um inglês na Îndia.

Mário de Andrade, ao contrário, permaneceu o homem urbano do Sul, que sempre foi, avesso aos esquemas prontos e habituado a pôr à prova,

25 ANDRADE, Mário de. Poesias completas. São Paulo: Martins, 1955, p. 365-71 
de tempos em tempos, as conquistas que vai fazendo. E se também reconhece que derivamos de uma cultura híbrida e em muitos pontos sem identidade, vê nisso um aspecto negativo, responsável em larga medida pela nossa insegurança e incapacidade de decisão. Tem uma extrema acuidade para apreender os traços característicos de nosso feitio, analisando-os de maneira impiedosa, mas sempre repassada de comovida identificação. Embora não seja cientista, mas escritor, desde moço adotou como norma "saber, saber, saber" apostar por princípio e, se preciso, "jogar tudo numa cartada só" Não para ganhar, mas pelo prazer do jogo. A viagem que fez ao Norte do país, pondo à prova a imagem que tinha forjado no Sul, através de leituras, foi uma das muitas apostas que fez e transformou, fundamentalmente, a percepção que, até aquele momento, tivera do Brasil

Embora de personalidades muito diversas e vistos freqüentemente como antagonistas, Mário de Andrade e Gilberto Freyre representam num dado momento, duas das posições mais interessantes e fecundas do pensamento nacional. Ambos conviveram desde cedo com a tradição popular e as manifestações de sua terra, e esse enraizamento com o poder revelador da imaginação prestigiou-os sobremodo, junto à juventude de seu tempo. Foi a partir deles que a geração de moços, que entre 1935 e 1940 saía da universidade, ainda não marcada pela especialização, começou a reavaliar o conceito de cultura, de identidade nacional, a discutir com isenção o problema da mestiçagem e os rumos que a arte brasileira devia tomar. As conquistas obtidas eram em geral provisórias e não se apoiavam na segurança racional dos sistemas. Mas, naquele momento de transição entre o sonho das vanguardas e a chegada vitoriosa dos especialistas, delineavam à nossa frente um recorte novo da realidade. Talvez uma invenção da realidade, como de tempos em tempos a arte efetua, para renovar o sentimento da divindade, do homem, ou mais humildemente da paisagem

\section{Post-Scriptum}

É provável que Mário de Andrade, meditando sobre o seu país, tenha sentido uma tensão semelhante à que Ernst Bertram viu em Nietzsche, da harmonização e reconciliação dos irreconciliáveis 26 A meditação que os dois fazem sobre o seu povo é semelhante, e certamente não foi por acaso que, em dado momento de sua trajetória intelectual, Mário de Andrade abandonou a

26 BERTRAM, Ernst. Nietzsche - essai de mythologie. Trad. de Robert Pitrou. Paris: Les Éditions, 1932. 
formação francesa e se voltou, como corretivo, para a cultura alemã. A multiplicidade informe que Nietzsche reconhece na alma alemã, a impressão caótica que ela provoca em Goethe e Hölderlin, é um pouco semelhante à da alma brasileira, retratada em Macunaíma. É curioso que Mário tenha se lembrado dos alemães na fase nacionalista, quando utiliza a temática nacional "à maneira do que fizeram os românticos alemães nos lieder, Goethe, Heine, Lenau" - como confessa em carta a Augusto Meyer. E que, como os alemães em geral e Nietzsche em particular, tenha procurado a identidade de seu país no afastamento da Europa, consciente da existência de um antagonismo visceral entre civilização e cultura.

A busca da realidade brasileira - da diferença em relação à Europa já se encontra esboçada em 1918, no artigo, "A divina preguiça" como lembra Telê Porto Ancona Lopez. A partir daí, em vários momentos da obra, nos ensaios como na ficção ou na poesia, irá opor, sistematicamente, as culturas dos climas quentes à dos climas frios; a mentalidade que ele chama de "paralógica" (do primitivo, da criança, do louco, do brasileiro inculto) à mentalidade lógica do civilizado, do adulto e do europeu. Para valorizar sempre a forma de sabedoria que se exprime na embriaguez e que, a seu ver, alcança na música o seu ponto extremo.

Por outro lado, ele deve ter sofrido, ainda, influência da filosofia alemã de impregnação nietzscheana por via indireta, através da teorização das vanguardas européias, da estética musical e sobretudo de Combarieu, que ele tinha em alta conta.

Bem mais fácil de localizar é a repercussão que tiveram em seu pensamento as idéias do filósofo alemão Max Scheler, sobretudo do ensaio "El porvernir del hombre" aparecido na Revista de Occidente ${ }^{27}$. que leu assim que chegou da sua viagem ao Norte, na primeira versão, ainda em espanhol. Neste escrito Max Scheler expõe, com muita clareza, o desequilibrado processo cultural que produziu no Ocidente "um tipo de homem sumamente unilateral, dominado pelo ascetismo do trabalho, da ganância, da acumulação ilimitada de bens econômicos" Este poder, voltado inteiramente para fora, e atuando sobre os homens e as coisas, sobre a natureza e o corpo, descuidou-se do domínio interior sobre a vida psíquica. Isto é, privilegiou o herói ativo, esquecendo o ideal contrário, o homem contemplativo, o sábio, difundido na Ásia, sobretudo no budismo primitivo, que "afronta as dores da existência mediante a arte real da paciência" |palavras de Max Scheler|

27 "El porvernir del hombre" Revista de Occidente (ano v, n 50, 11.8.1927). 
Mário de Andrade deve ter-se entusiasmado com esta conceituação que, ligada a toda uma corrente da filosofia alemã, vinha ao encontro daquilo que, há tempos, queria formular: que o modelo oriental de cultura teria sido mais adequado às condições geográficas do Brasil. É provável que ao conceber o maleitoso como a forma de sabedoria de um homem perfeitamente sintonizado com a paisagem tenha se lembrado de Max Scheler.

Gilda de Mello e Souza é professora aposentada da Faculdade de Filosofia da Universidade de São Paulo. Autora de O tupi e o alaúde: uma interpretaçāo de Macunaima [Duas Cidades, 1979] e O espirito das roupas: a moda no século xIX [Cia. das Letras, 1993], entre outros.
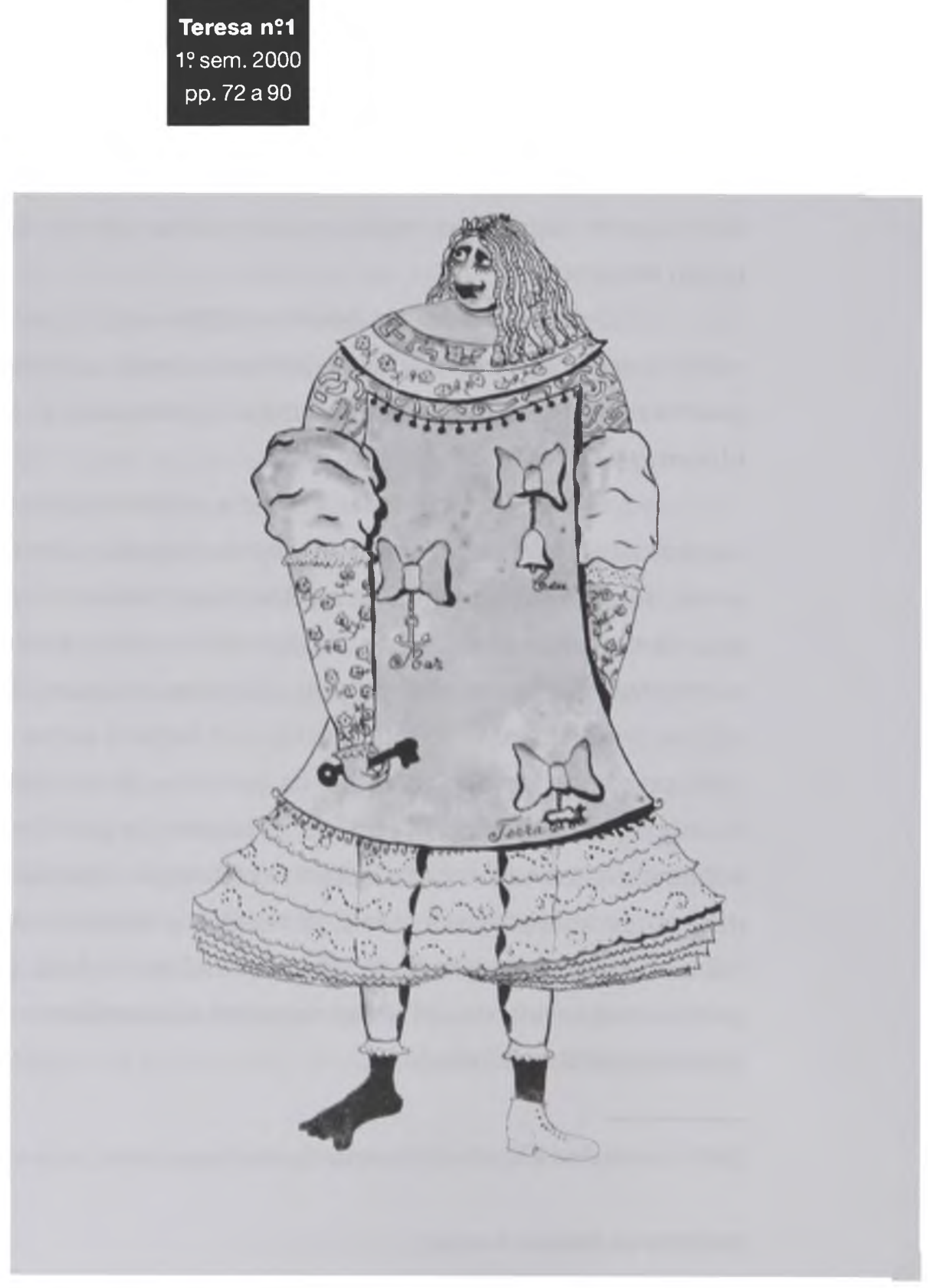


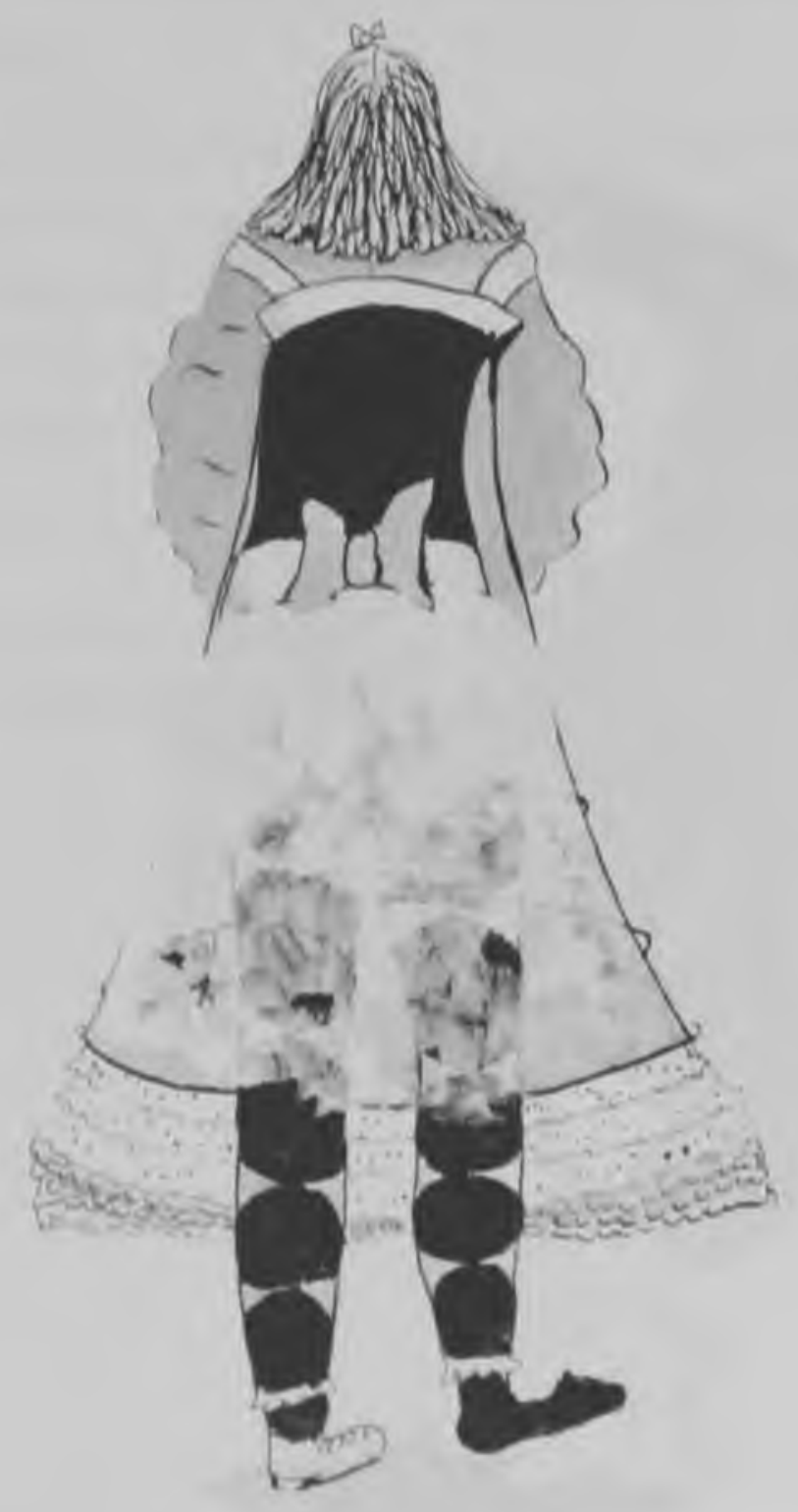

